\title{
NICKEL-CADMIUM BATTERY CELL REVERSAL FROM RESISTIVE NETWORK EFFECTS
}

\author{
Albert H. Zimmerman \\ The Aerospace Corporation \\ Los Angeles. California 90009
}

\begin{abstract}
AB
During the individual cell short-down procedures often used for storing or reconditioning NiCd batteries, it is possible for significant reversal of the lowest capacity cells to occur. The reversal is caused by the finite resistance of the commor current-carrying leads in the resistive network typically generated during short-down. A model is developed to evaluate the extent of such reversal in any specific battery, and the model is verified using data from short-down of a 4-cell, 3.5 Ah battery. Computer simulations of short-down on a variety of battery configurations indicate the desirability of controling capacity imbalances due to cell configuration and battery management, limiting variability, in the short-down resistors, minimizing lead resistances, and optimizing lead and battery configurations.
\end{abstract}

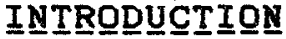

Nickel-cadmium (NiCd) battery cells are often stored during extended periods of inactivity in a totaily discharged state, usually with a shorting connector across the terminals of each cell. Much evidence points to this being the optimum storage mode, particulariy at reduced temperature. In addition, a growing body of data also indicates that periodic total discharge of individual cells in a battery is an extremely useful way of reconditioning and balancing cell performance, and thus extending the operational life of a $\mathrm{NiCd}$ battery. For a battery of series-connected cells, the process of total discharge must generally be done for each cell independently, so. that the iower capacity cells wili not be series driven into reversal by the higher capacity cells. A particularly sinple way to accomplish an independent iischarge for each celi is merely to place a resistor (typically 1 ohm) across each cell and aliow the cell to discharge for an extended period of time. For batteries this is often done by attaching shorting resistor assembly to voltage sensing wires at a battery connector.

Typicai battery short-down procedures involving discharge of more than one cell at a time do not provide for totally independent discharge of each celi. This situation arises simply because of the finite resistance in the current-carrying wires comon to adjacent cells. The short-down procedure actually creates a resistive network in which coupling between adjacent celis must always exist as long as any lead resistance is present, as indicated in Fig. i.

Because of the coupling effects of lead resistances, there is a distinct possibliliy that the lower capacity celis will be driven into reversal by the higher capacity cells, even when individual resistors are connected across 
each ceil. The driving forces for such reversal should be generaliy minimizec by maintaining capacity balance, minimum lead resigtance, optimized celi configuration. and appropriate short-down procedures. In this report the network of Eiq. 1 is analyzed as a function of cell characteristics, lead resistance, and shorting resistance. The extent of ceil reversal that may realistically be expected is calculated for typical battery short-down configurations. Test data are aiso presented to support the model for a 4-celi $\mathrm{NiCd}$ battery consisting of $3.5 \mathrm{Ah}$ "D" cells. Finally conclusions are provided to indicate how to minimize the possibility of celi reversal during individual cell short-down.

\section{NEETWORK ANALYSIS}

For the network of $\bar{F}$ ig. i, the celi currents $I_{n}$ must be determined as a function of the celi voitages $V_{n}$. the shorting resistances $S_{n}$, and the ieac resistances $\beta_{n}$. For each celi $n$, the appilcation of Kirchhoff's laws shows that tie current through the shorting resistor. In must equal the cell current. The voltage of each ceil is equal to the sum of the voltage drops around each loop. 1.e..

$$
V_{n}=I_{n} S_{n}+R_{n}\left(I_{n}-I_{n-1}\right)+R_{n+1}\left(I_{n}-I_{n+1}\right)
$$

Which nay be rearranged to

$$
V_{n}=I_{n}\left(S_{n}+R_{n}+R_{n+1}\right)-I_{n+1} R_{n+1}-I_{n-1} R_{n}
$$

The reiationships between voitage, current, and resistance are thus simpiy reduced to the equation

$$
\underline{R} \underline{I}=\underline{V}
$$

where $\underline{R}$ is the $n-b y-n$ network resistance matrix with elements

$$
r_{\mathbf{i} j}=\left(S_{\mathbf{i}}+R_{\mathbf{i}}+R_{\mathbf{i}+1}\right) \delta_{\mathbf{i} \mathbf{j}}-R_{\mathbf{j}} \delta_{\mathbf{i}+1, \mathbf{j}}-R_{\mathbf{i}} \delta_{\mathbf{i}-1, \mathbf{j}}
$$

witere $\delta_{i j}$ is the deita function. The diagonal term in Eq. 4 represents the discharge paths expected for ideal individual cell discharqe. The off-diagonai cerms represent the coupling of each ceil through the network to other discharging ce:is. The current and voitage in Eq. (3) are both n-element coiumn vectors with elements $I_{n}$ and $V_{n}$, respectively. Equation (3) may be soived for either the ceil voitages $V_{n}$ if the currents $I_{n}$ are known, or the currents may be determined if the voltages are known.

\section{EXXPERIMENI}

To evaluate how the analysis of the previous section can be appiied to Da: zery isscharge, a s-ceil battery and resistance network were prepared having the values given in Table 1 . The cells were 3.5 Ah NiCc "D" ceis. The voitage and current of each cell was monitored as a function of time during the discharge through the resistors. The battery was typically charged for 16 
h at $c / 10$ foliowing at ieast a i6-h short-down.

The first test involved charging cells 1 through 3 only, discharging these three celis for $2.5 \mathrm{~h}$ at $1 \mathrm{~A}$. then resistively shorting down all four ceils using the network defined in Table?. The observed voltage behavior for the four cells is indicated in Fig. 2, where the points indicate the voltage calculated from Eq. (3) and the lines indicate the experimentally measured voltages. Cell 4, which is totally discharged, remains in reversal for about $2.5 \mathrm{~h}$. The reversal current depends on the voltages of the other cells, but was as high as $94 \mathrm{ma}(\mathrm{C} / 37)$ eariy in the reversal. The good agreenent between the experimental data and the calculated points in Fig. 2 indicates that the network model of Fig. i can accurately describe the behavior of battery cells curing individual cell short-down.

The second tegt involved connecting the shorting resistor to ce:l $4, ? \mathrm{~h}$ before shorting down the other cells, thus creating about a $i$ ah lower capacity in ceil 4. As indicated in Fig. 3, celi 4 was still driven into zeversal for about $12 \mathrm{~min}$ with a maximum reversal rate of 92 ma. The third test was similar. to the second test except that short-down was begun 1 h earlier on cell 3 rather than cell 4. The results are indicated in Fig. 4. The reversal rate was $172 \mathrm{~mA}$ at its maximum, about twice that of the previous test, presumsily because during most of the reversal period the cells on each sida of cei: 3 had high voltages. In the third test the cell was in reversa: for $32 \mathrm{~min}$. These resuits suggest that during short-down the end cells in a series string have a much more benign environment with regard to reversal.

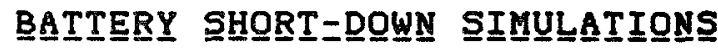

The short-down of a battery containing $n$ celis was simuiated by a computer model. The inputs to this model consisted of shorting resistances, iead resistances, the capacity of each cel1. and a current-voitage reiationship as a function of residual capacity discharged from the depleted cel:.

The current-voitage relationship that was used in the simulations was cerived from short-down data for 3.5 Ah cells having 1 ohm short-cown resistors. and is meant to provide only a representative current-voltage relationship during short-cown. Each cell was assumed to have a constant voltage of i.15 volts until its capacity was depleted, after which the voltage ceceased ineariy to 0.2 volts during the discharge of an additional 0.04 Ah. Thereafter each ce:l was assumed to have a voltage given by

$$
v_{n}=0.317 \times 10^{-5 Q}-\Delta I\left(1.228 \times 10^{-1.226 \Delta I)}\right.
$$

where $Q$ is the residual capacity discharged in $A h$, and $\Delta I$ is any discharge current in excess of that anticipated from the diagonal terms in Eqs. (3) and (4). Equation (5) was obtained empirically by fitting the voitage of one cell curing short-down. When the voltage is negative, a voltage limitation of $v_{n}=$ $-0.06 \log ( \pm 10.000: 4)$ is used to give a reasonable asymptotic dependence for hycrogen evolution. While this model is only approximate, it provides a reasonabie empirical representation of the short-down behavior with : onm resistors, which can be used for evaluating trends in the short-down behavior. 
The first computer simulation was for a 4-cell battery using the shortdown parameters of Table 1, 3.5 Ah of capacity for cells 1 through 3, and 2.5 Ah for ce:l 4. The trends in the simulation should therefore be directly comparajie to the data in Fig. 3. The results of the simulation, indicated in Fig. 5. ciearly show the same features as the data in Fig. 3.

The second computex simulation was done for a 22-cell battery where 1 ce:: was assumed to have 1 Ah iess capacity than the other 21 cells, and the pusition of the low-capacity cell was varied from one end to the middle of the Se:i string. Ail shorting resistors were 1 ohm and all lead resistances were C.: ohm. The results of tisis simulation, preaented in Fig. 6, clearly show that the end ceil shou:d be subject to considerably less reversal than cells of eculi capacity situated away from either end of the cell string.

A third simuiation was done to determine the effect of varying the lead resistarce on the cell reversal. An 11-cell battery was simulated, with the Ah in reversal during short-down piotted as a function of lead resistance in Fig. 7. The center celi was assigned I Ah less capacity than the other cells. so it is the cel: being reversed in Fig. 7. All short-down resigtances were 1.0 ohm. From the results in Fig. 7, approximately $0.025 \mathrm{ohm}$ of lead resistance are required before reversal occurs under these conditions of simulation. The aliont of reversal increases in a neariy linear fasnion as the lead resistance is incressed reiative to the shorting resistance.

It is expected that the amount of cell reversal should increase as capacity imbalance increases. In Fig. 8 a fourth simulation is presented in wich the capacity imbalance is varied and both the capacity and the time in reversai are piotted. This simuiation is for an 11 -cell battery whose center ce:- is :ow in capacity; shorting resistors are $1.0 \mathrm{ohm}$, and lead resistances are $0 . j$ ohm. Both capacity and time spent in reversal increase with increasing capacity imbalance. However. if the imbalance is near 2 ah or higher, the low ce:l wil: stay in revergal long after the other cells are depleted, since it has been taken down far enough in capacity that even the low residual voltages present for the other cells can hold the low cell in reversal. The data in Fig. 8 clearly indicate the need to avoid conditions that can lead to large imbalances in capacity.

Capacity imbaiances between the cells of a battery are generally contro:iec to less than $5 \%$ of the total capacity by cell matching procedures. However. extended periods of open-circuit stand, cycling, or other enviromental considerations may temporarily create greater imbalances. If a nornal distribution of cell capacities is assumed for an 11-cell battery, and these ceiss are arranged in order of increasing capacity in the battery, it was not possibie to reverse any of the cells in a computer simulation where the totai spread of capacities was aijowed to go up to $1 \mathrm{Ah}$. This is because acjacent ceils are never very different from each other in capacity. Adjacent calis would probabiy have to differ by 0,3 an or more to get reversal in this configuration. On the other hand, if the cell arrangement is changed so that high-capacity and jow-capacity cells alternate without any change in the overail ceil capacity distribution, extensive reversal becones possible. This is simulated in Fig. 9. where the extent of reversal is plotted as a function of the An spread in an 1:-cell battery, assuming a normal distribution of capacities. The cells aiternate in capacity so that cells 2, 4, and 6 are the three jowest capacity celis. The results in Fig. 9 indicate that when capacity imbaiances are possible, it is very likely that several cells can be driven 
into reversal simultaneously.

A final situation that can lead to significant imbalance in cell capacities in a battery is the effect of unmatched short-down resistors being used to take a battery down from a high state of charge. This effect causes some ceils to discharge faster than others, so that large imbalances in capacity can exist when the firat cell reaches depletion, even if all the ceils were closely matched at the start of discharge. The effect is simulated in Fig. 20, where both the extent of reversal and the effective cell imbalance are plotted as functions of short-down resistor inbalance. The simulation started with a fuily charged 3.5 Ah battery containing 11 cells, of which the center cell has an imbalanced short-down resistor. The initial capacity spread between high and low cell was $0.3 \mathrm{Ah}$ and followed a normal distribution. The cells were arranged in an alternating high-low capacity arrangement. Fig. 10 indicates that a 15 to $20 x$ inbalance in short down resistors can add $0.7 \mathrm{Ah}$ to the imbalance between celis and can cause extensive reversal. The situation of inbalance due to variations in short-down resistors can be easily managed by either using matched resistors, or by discharging battery capacity as a series cell string until the lowest cell is depleted before the short-down resistors are connected.

\section{SONCLUSIIONS}

The results presented here indicate that significant reversal of the Lowest capacity cells can result from individual cell short-down of a NiCd battery. A model has been presented that provides a straightforward way to evaluate the risk of cell reversal for a particular battery or a particular short-down procedure. The consequences of cell reversal are likely to be ( 1 ) some hydrogen evolution. although not enough to overpressurize the cell; and (2) significant $\mathrm{Cd}$ reduction at the $\mathrm{Ni}$ electrode, possibly leading to $\mathrm{Cd}$ cendrite short-circuits. Such short-circuits, if formed, will be oxidized during recharge and are not expected to have any lasting inpact on performance.

This report suggests a number of points that are important in mininizing the possibility of cell reversal, es follows:

1. Mininize capacity imbalances that may arise from uncontrolled battery handling or storage. This is particularly important during integration and test procedures.

2. Do not discharge battery capacity from a high state of charge by using individual cell short down. Discharge the battery as a series string of cells until the lowest capacity cell is depleted, then apply shortdown resistors to individual cells.

3. Use 1\%-tolerance resistors for short-down.

4. Minimize lead resistance relative to the resistance of the short-down resistors. Lead resistance includes that of leads internal to the battery assembly, plus that of any cable used to connect the battery to a breakout box where the short-down resistors are attached. The uitimate solution to minimize lead resistance is to attach the shortdown resistors at the cell terminals, or to attach separate leads at 
each cell terminal.

5. The arrangement of cells'within a battery is critical. The optimum arrangement for mininizing the possibility of ceil reversal is to order the series string of cells in terms of capacity, from high at one end to low at the other end. This procedure makes it difficuit to reverse any cell in the string during short-down as long as the spread in cell capacities does not increase significantly beyond the initial spread typically allowed in $\mathrm{NiCd}$ batteries.

6. The end cells in the series-connected string are always less subject to reverse diacharge during individual cell short down than the other ceils in the battery. 
Table 1. EXPERIMENTAL BATTERY NETWORK PARAMETERS FOR 4 CELLS CONNECTED IN SERIES (3.5 A h)

\begin{tabular}{lr}
\hline Lead Resistance, $\Omega$ & Shorting Resistance, $\Omega$ \\
\hline$R_{1}=0.0721$ & $s_{1}=1.045$ \\
$R_{2}=0.0786$ & $s_{2}=0.940$ \\
$R_{3}=0.0878$ & $s_{3}=0.991$ \\
$R_{4}=0.0942$ & $s_{4}=0.974$ \\
$R_{5}=0.0879$ & \\
\hline
\end{tabular}




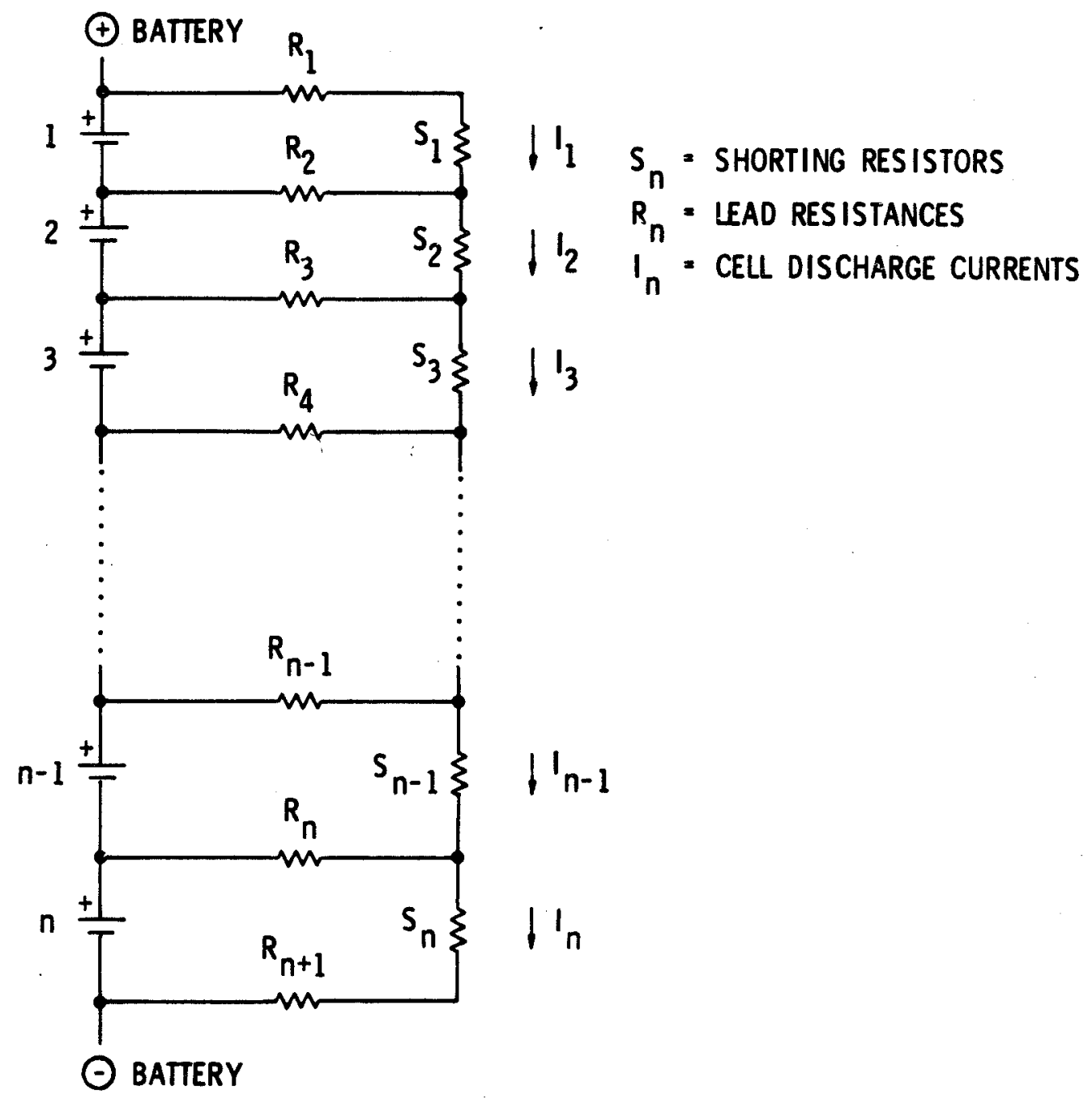

Figure 1. Resistive Network Created during Individual Cell Short-down of an N-Cell Battery 


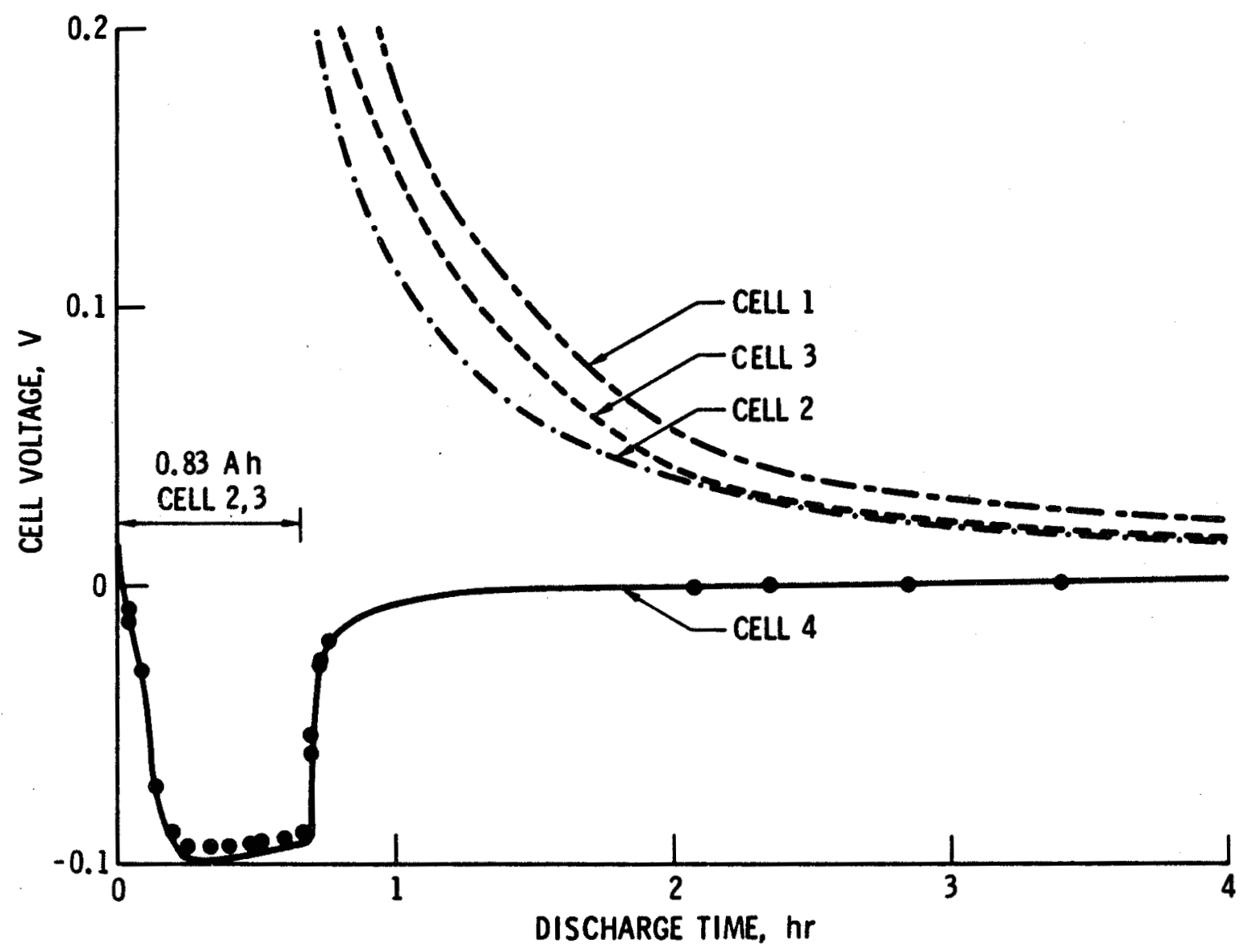

Figure 2. Short-down of a 4-Cell Battery; Cell 4 is Totally Discharged and Cells 1 Through 3 Have $\sim 1-$ A h Capacity 


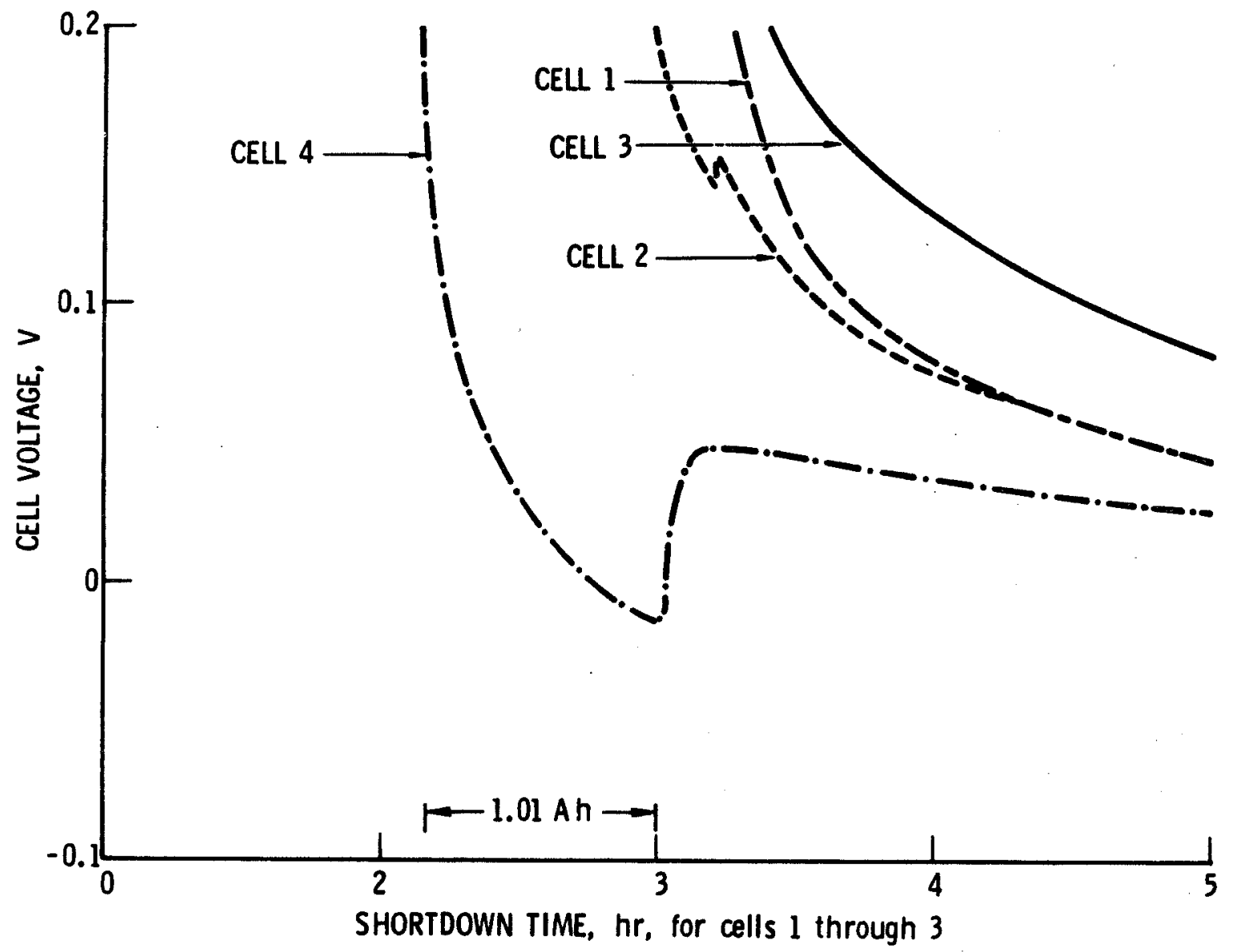

Figure 3. Short-down of a 4-Cell Battery; Cell 4 Discharge Started $1 \mathrm{hr}$ Earlier Than Did That of the Other Cells 


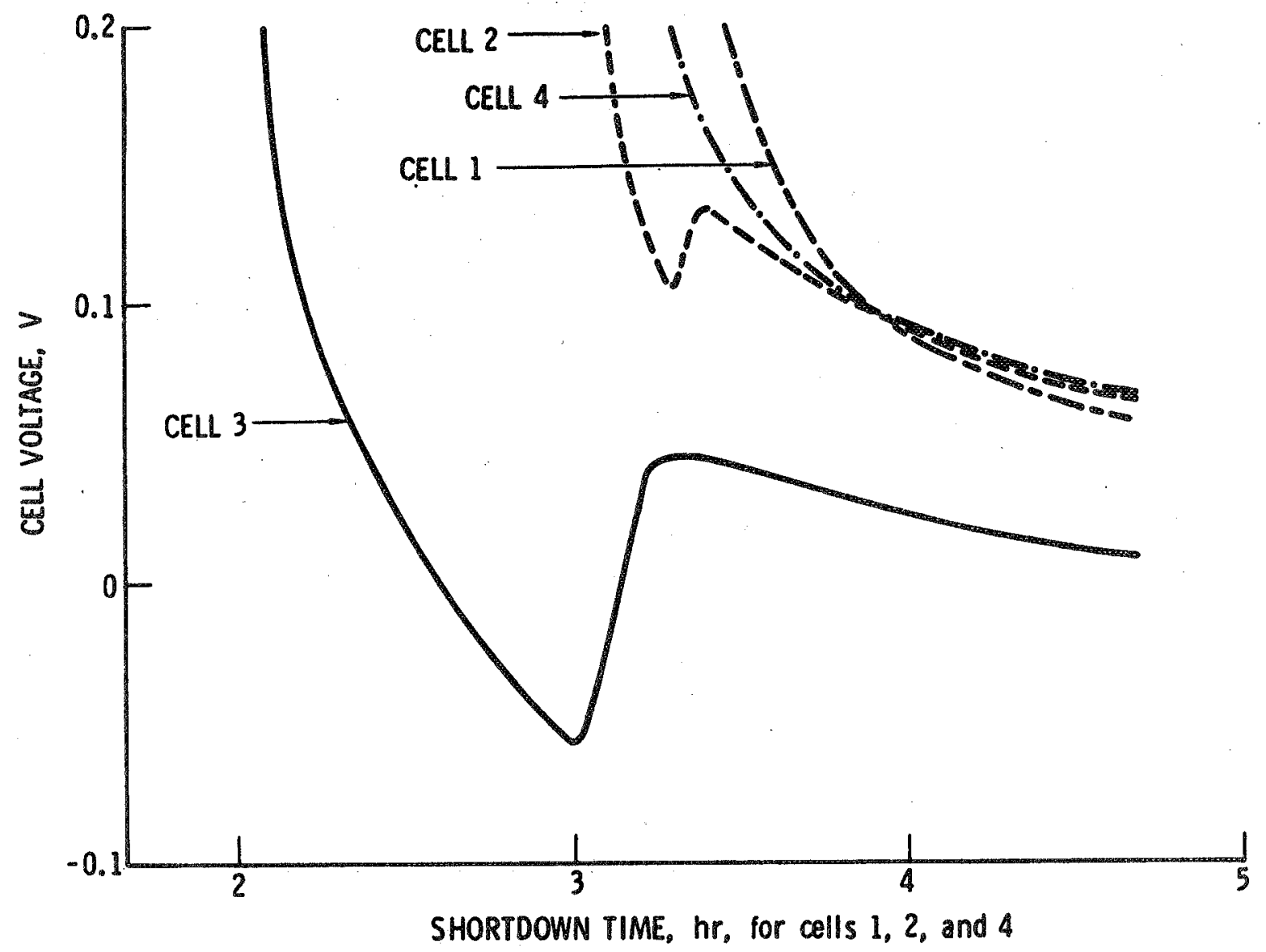

Figure 4. Short-down of a 4-Cell Battery; Cell 3 Discharge Started $1 \mathrm{hr}$ Earlier Than Did That of the Other Cells 


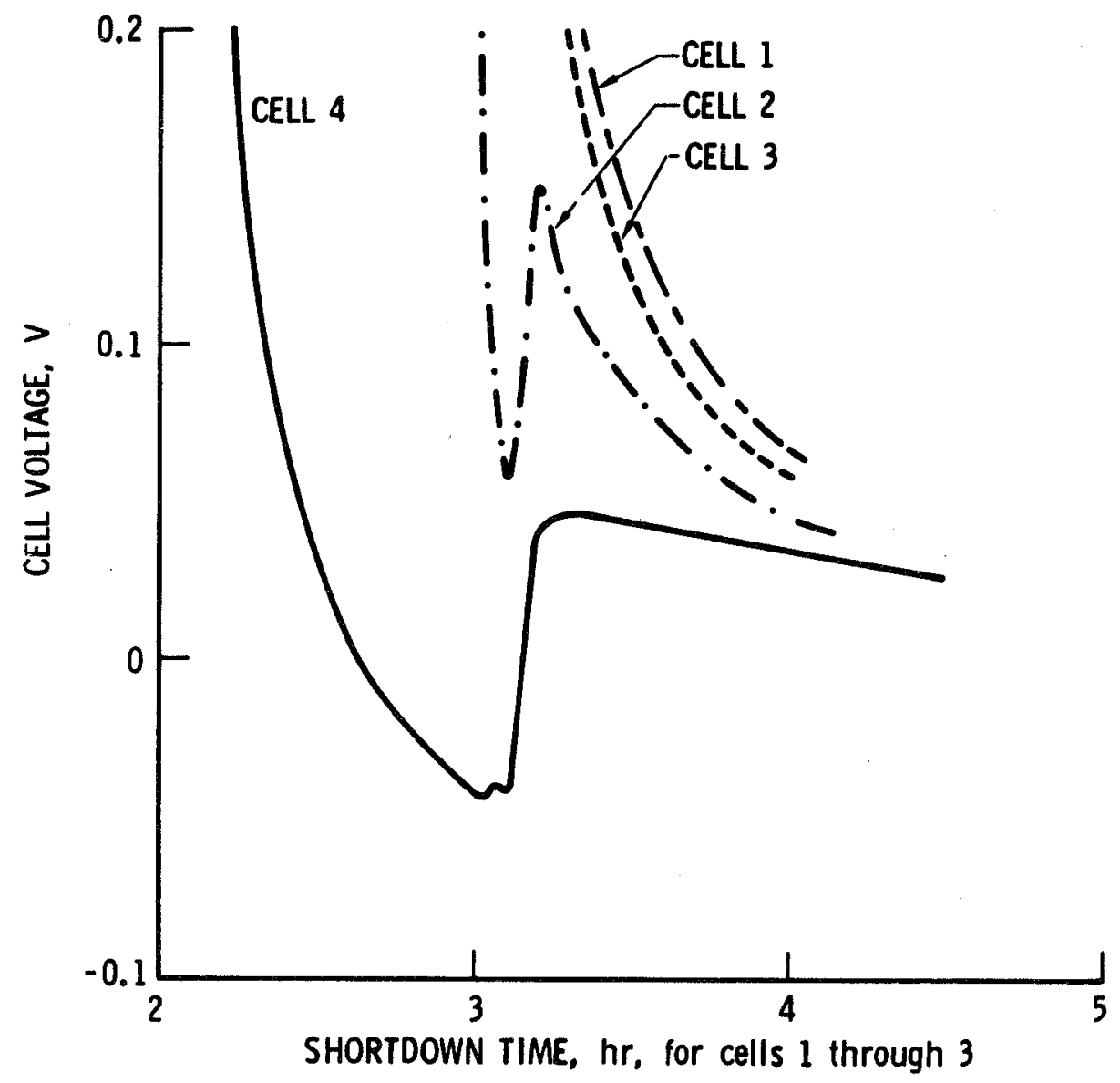

Figure 5. Short-down Simulation for a 4-Cell Battery, with 3.5 A h in Cells 1 Through 3, and $2.5 \mathrm{~A} \mathrm{~h}$ in Cell 4 


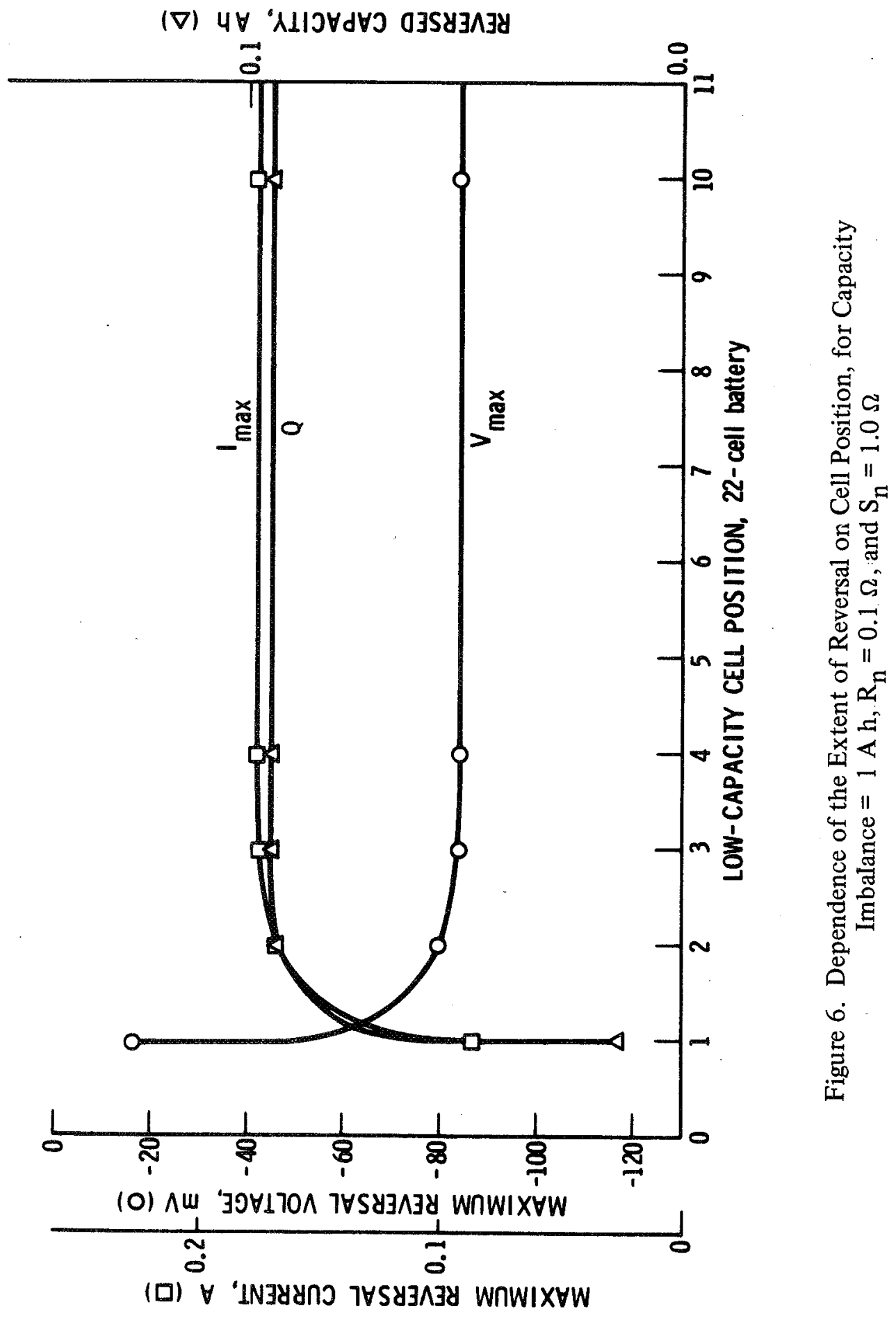




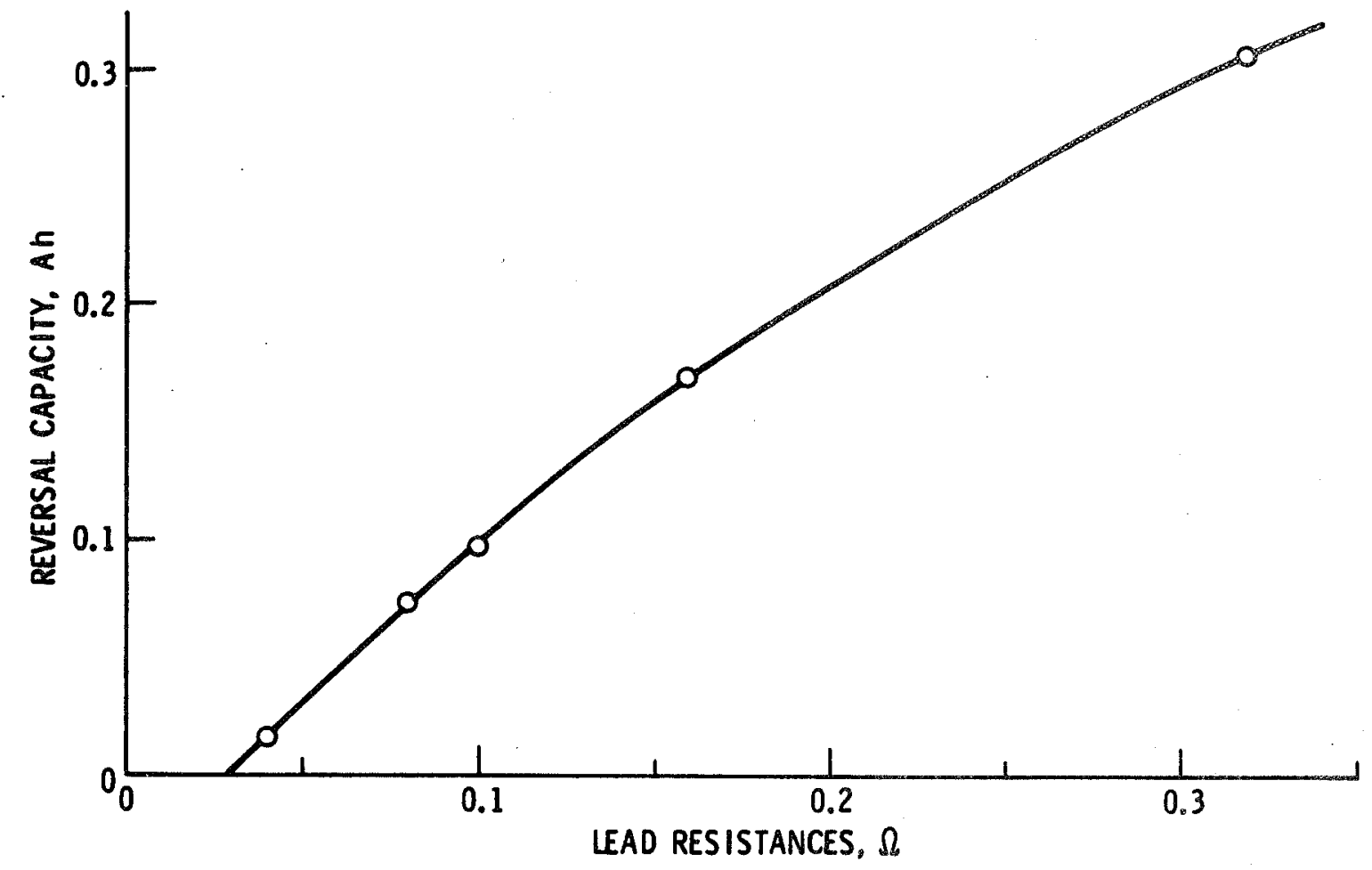

Figure 7. Extent of Reversal as a Function of Lead Resistance for the Center Cell of an 11-Cell Battery, for Capacity Imbalance $=1 \mathrm{~A} \mathrm{~h}$ and $S_{\mathrm{n}}=1.0 \Omega$ 


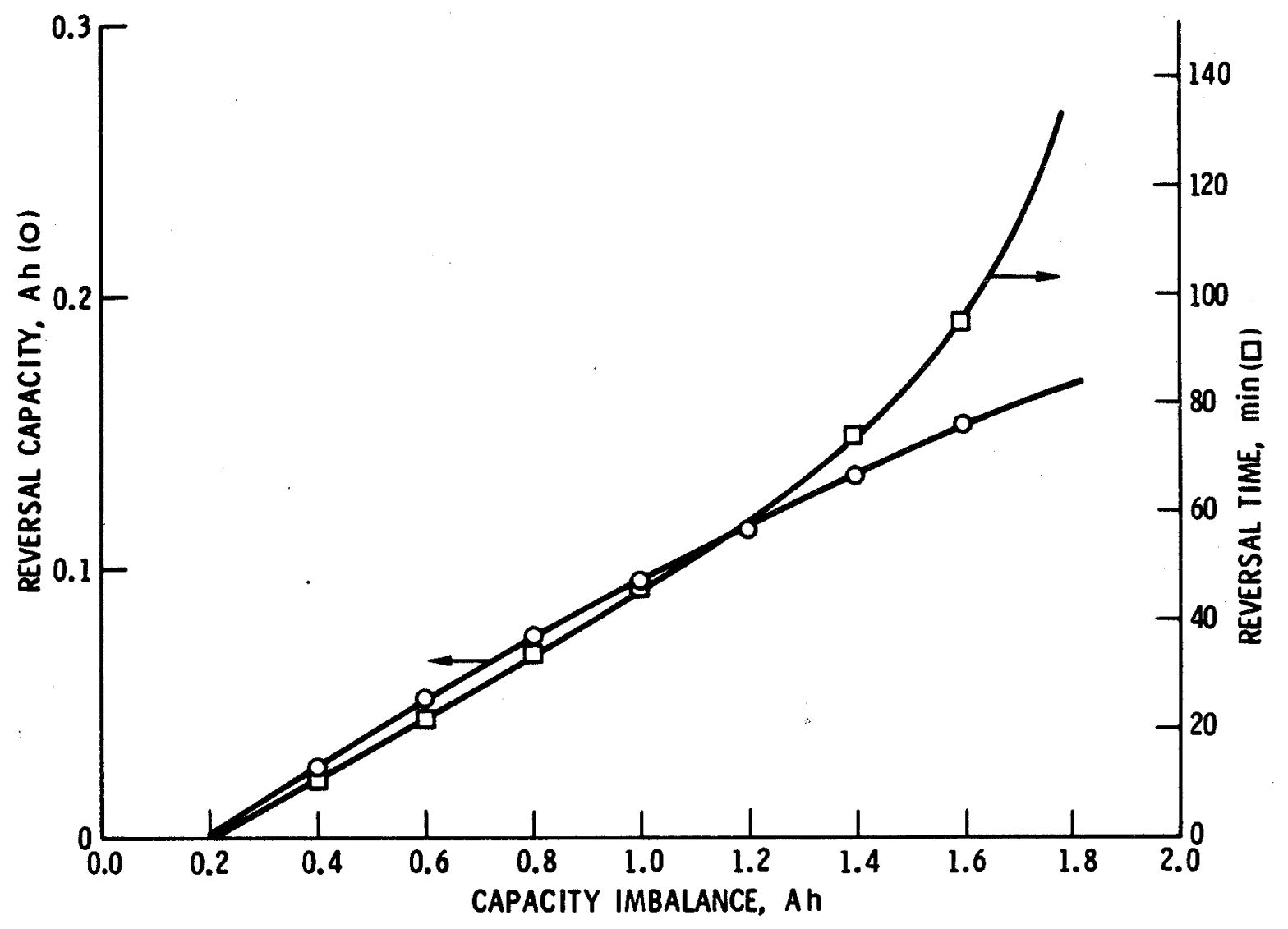

Figure 8. Extent of Reversal as a Function of Capacity Imbalance in the Center Cell of an 11-Cell Battery, for $S_{n}=1.0 \Omega$ and $R_{n}=0.1 \Omega$ 


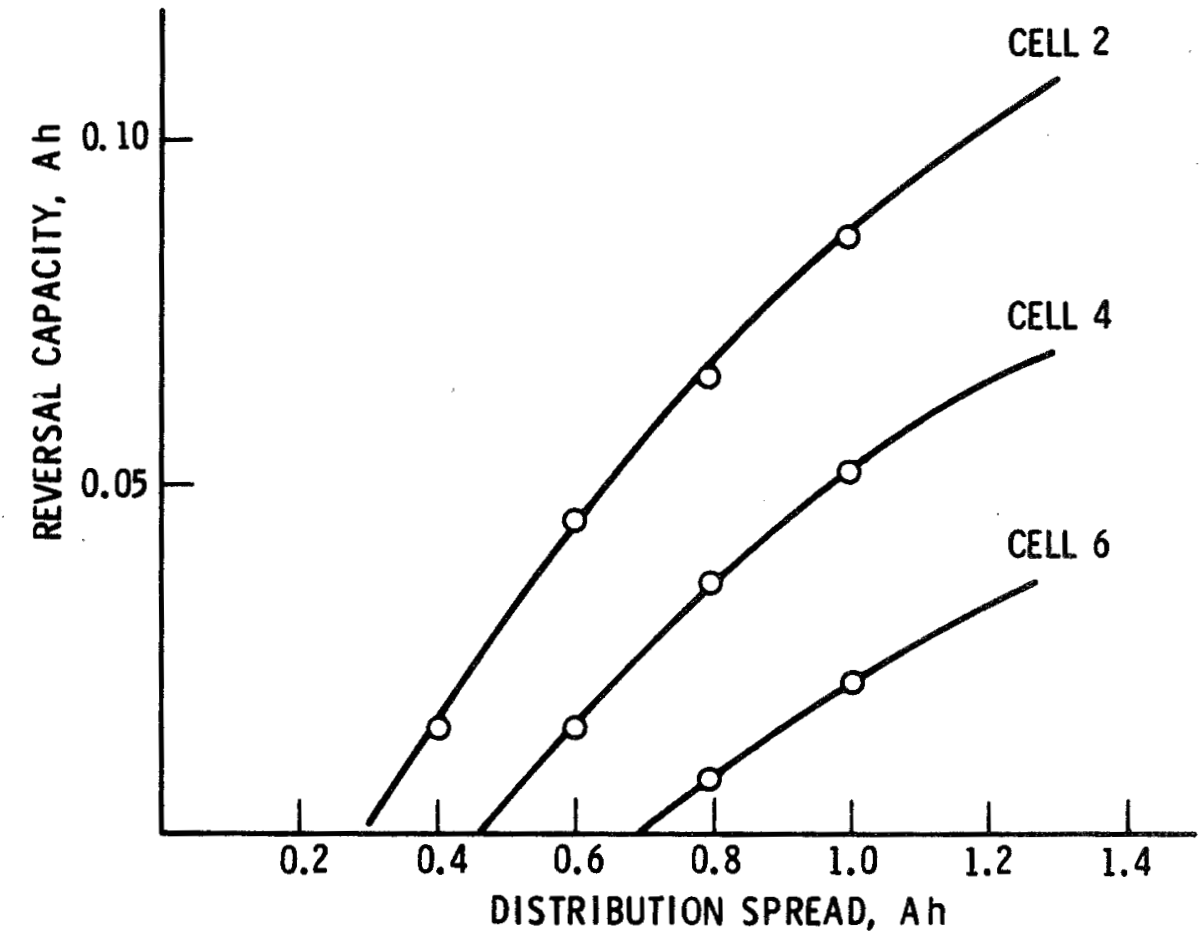

Figure 9. Extent of Reversal as a Function of Capacity Imbalance in an 11-Cell Battery Having Normal Capacity Distribution (High/Low Alternation of Cells), for

$$
\mathrm{S}_{\mathrm{n}}=1.0 \Omega \text { and } \mathrm{R}_{\mathrm{n}}=0.1 \Omega
$$




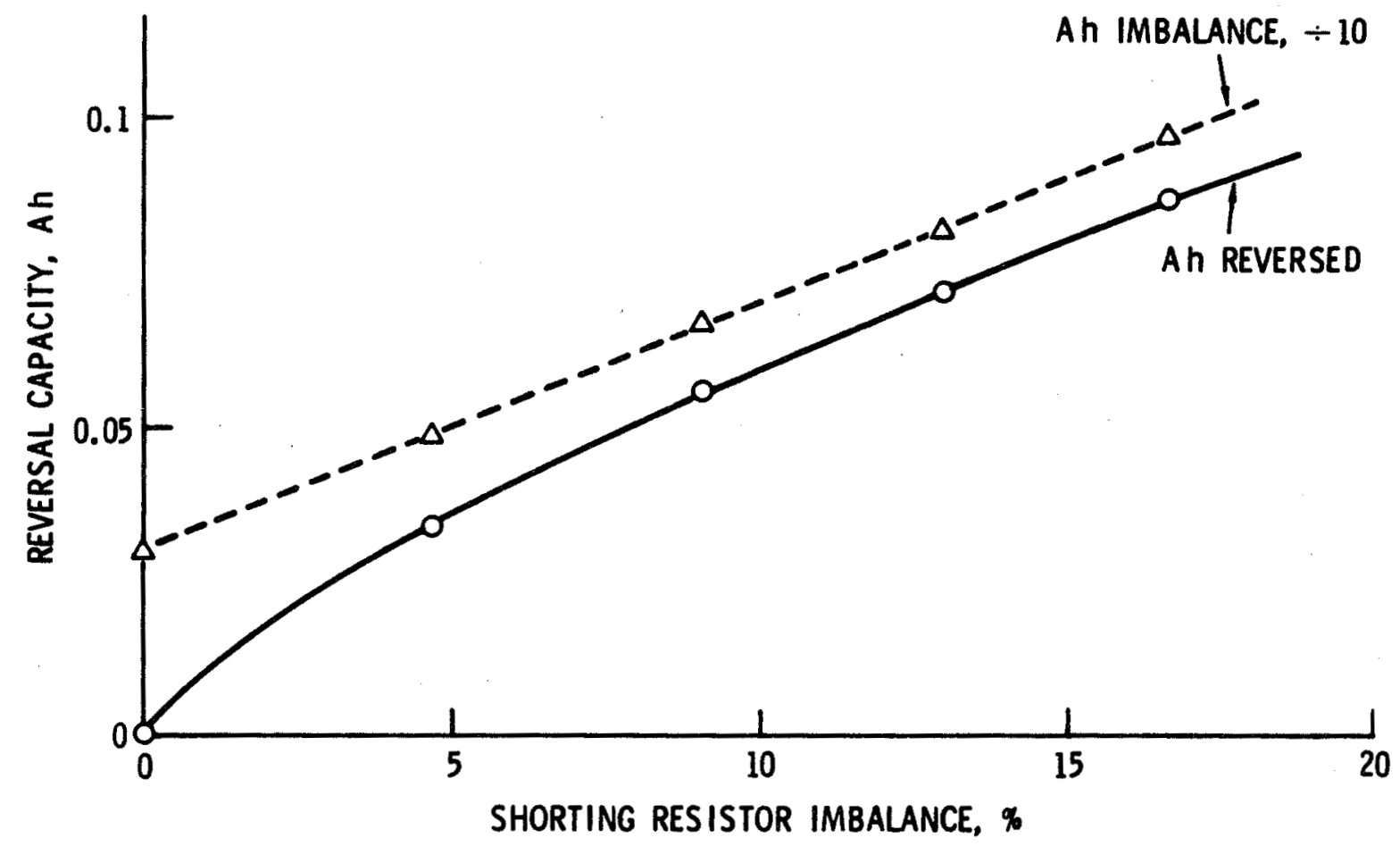

Figure 10. Short-down of Fully Charged Battery vs. Shorting-resistor Imbalance for Capacity Imbalance $=0.3 \mathrm{~A} \mathrm{~h}$ and $\mathrm{R}_{\mathrm{n}}=0.1 \Omega$ 